\title{
Book Review: Selection Procedure and Inclusion of Intellectually Disabled People in the Workplace
}

\author{
Resenha: Procedimento de Escolha e a Inclusão \\ de Deficientes Intelectuais no Contexto de Trabalho
}

\author{
Reseña: Procedimiento de Elección y la Inclusión \\ de las Personas con Discapacidad Intelectual en el Trabajo
}

\begin{abstract}
Book Review: Escobal, G. E. \& Goyos, C. (2015). Trabalho de indivíduos com atraso no desenvolvimento intelectual. Contribuições da Análise do Comportamento Aplicada (ABA) e Processos de Tomada de Decisão. São Carlos, SP: Editora Universitária da Universidade Federal de São Carlos.
\end{abstract}

Dafne Pavanelli Fidelis ${ }^{1,2}$ *

Orcid.org/0000-0002-2959-5445

Pedro Bordini Faleiros ${ }^{1}$

Orcid.org/0000-0003-3368-1415

${ }^{1}$ Universidade Metodista de Piracicaba, Piracicaba, SP, Brasil ${ }^{2}$ Instituto LAHMIEI - Universidade Federal de São Carlos, São Carlos, SP, Brasil

\section{About the Authors}

Celso Goyos is an Associate Professor at the Department of Psychology at the Federal University of São Carlos (UFSCar). He has a PhD in Experimental Psychology from the University of São Paulo and was a Postdoctoral Researcher at the University of Wales and the University of California. Giovana Escobal is a Research Associate at the Department of Psychology at UFSCar. She graduated in Pedagogy from UFSCar and has a Master's degree and a PhD in Special Education. She was a Postdoctoral Researcher in Psychology at the same university. Both authors have published in the areas of Behavior Analysis, Autism and Decision Making.

\section{The Aim of the Book}

Public policies emphasize the importance of promoting, inserting and the inclusion of individuals with disabilities in the labor market. Although there are such policies, for instance the Quota Law (Law No. 8213,1991$)$ to ensure the right of people with all types of disability to enter the labor market, generally job vacancies in companies are filled by people with physical, auditory or visual disabilities.

* Mailing address: Rodovia do açúcar, Km 156, Taquaral, Piracicaba, SP, Brazil. E-mail: dafnepfidelis@hotmail. com 
According to Pereira-Silva and Furtado (2014), Toldrá, De Marque, and Brunello (2010) and Veltrone and Almeida (2010), rarely are people with intellectual disability hired. Data presented in the 2010 Census about disabled people indicates that from the total number of vacancies filled by people with some type of disability, approximately $20 \%$ are occupied by workers with intellectual disability (Cartilha do Censo, 2010).

The book entitled "Individuals' Work with Delayed Intellectual Development", written by Giovana Escobal and Celso Goyos, which is the result of the first author's doctoral thesis supervised by the second author, presents a methodological model for behavior analysts about the inclusion of people with intellectual disabilities in a work context and discusses ways of working with this population, aiming at greater autonomy, dignity and inclusion. The main objectives presented in this research are:

1. To teach prerequisites for choice responses;

2. To analyze the choice behavior of adults with intellectual disabilities considering two work alternatives, with and without instructional arrangement; and

3. To evaluate the influence of the conditions with and without choice on the performance of these participants.

\section{Book Summary}

In the first chapter, Escobal and Goyos show the importance of making choices, affirming that it is part of the basis of the decision-making process and problem-solving process. Afterwards, the authors argue that Behavior Analysis proposes a solid methodology to investigate, acquire, maintain and change choice behavior, adopting procedures of simple concurrent schemes with concurrent threads. Furthermore, this theoretical conception also uses instruments and manipulates different experimental conditions, such as possibilities with or without the choice of an instructional arrangement, which enables people with intellectual disability to perform tasks and encourages their autonomy.

The second chapter addresses the participants' identification, location, material resources and procedures carried out in the research. The preliminary procedure is also presented in-depth, whose objective is to teach prerequisites and analyze the participants' choice responses with and without instructional arrangement and adapted instructional arrangement. The procedure entails four steps for teaching the work task with and without instructional arrangement:

1. Teaching the work task with and without instructional arrangement separately;

2. Teaching the work task with and without instructional arrangement alternately;

3. Teaching the work task with and without instructional arrangement alternately with adapted arrangement; and;

4. Teaching the work task with and without instructional arrangement alternately.

The work task consisted of making notepad covers; the instructional arrangement included a utensil for putting shredded paper, the backs of notepad covers and glue; and the adapted instructional arrangement had a white fluorescent lamp attached to the upper end which was intended to make the work task more discriminable. Throughout the chapter, the work task and the instructional arrangements are illustrated by images, so that the reader can have a clearer idea of the materials and methodology used.

The procedures to teach choice responses were followed using four key steps:

1. Teaching the choice response;

2. Teaching the choice response under concurrent and multiple schemes;

3. Teaching the choice response with work alternatives; and;

4. A discrimination test of the relationship between buttons and work alternatives. Afterwards, the participants went through four new phases, which sought to identify the participants' preferences for opportunities with and without choice, as well as with and without instructional arrangement. The experimental design used was $\mathrm{ABAB}$ reversion, coupled to a multiple-element design. Data analysis was carried out using relative rates of choice response and performance analysis. 
The third chapter describes the performance of the participants following the order of exposure of procedures of the phases and stages they went through. This way of presenting the results helps the reader to understand better the sequence of experimental conditions that the participants were exposed to and the results obtained. In general, all participants showed a preference for the alternative with instructional arrangement and gave more responses for the condition with choice.

In the fourth chapter, the authors relate the results found from other research in the area, highlighting the gaps of the experiment and also possibilities of future studies that could be designed to control variables that were not manipulated in the present experiment, such as the quantity of items made available in the condition with choice. In the final considerations, Escobal and Goyos discuss the importance of the opportunity of choice and that instrumental arrangements can help individuals with intellectual disabilities to develop their autonomy, self-determination and greater performance at work.

\section{Contributions of the Book}

The book provides behavioral analysts with important information and knowledge about possible methods to help people with intellectual disabilities develop choice skills in a work situation. The authors emphasize the importance of the opportunity of choice for this population, as it is likely that throughout life, they have hardly had the opportunity to opt for something.

According to Lattal (2004), both basic and applied research influences one another and cannot operate separately because both are controlled by a set of subjects and unique circumstances in their natural environments. Escobal and Goyos, empirically demonstrating that instrumental arrangements can help people with intellectual disabilities to perform in the labor market, emphasize the importance of interaction between experimental and applied research in the investigation of choice behavior for people with intellectual disabilities.
The prevailing conception in society that disability is an attribute of the individual that makes him/her incapable mostly prevents professionals, family members and even the individual him/herself from considering the possibility of the latter to learn and develop work-related behaviors. The research carried out by Escobal and Goyos recognizes the importance of adopting procedures that can acquire repertoires and help with inclusion of people with intellectual disabilities in the labor market.

It should be noted that the inclusion process of the disabled does not only take place by learning specific skills for a work activity. We must also consider multiple factors, such as the physical environment itself and especially the social context in which the individual can be inserted. However, promoting repertoires that help individuals (considered deficient) to have autonomy, such as making choices, will allow them to significantly change the social environment in which they live. As a result, this will contribute to the inclusion of people with intellectual disability and their behaviors may change and be changed by the context in which they live.

\section{References}

Cartilha do Censo. (2010). Pessoas com deficiência. Retrieved from http://www.pessoacomdeficiencia.gov.br/app/sites/default/files/publicacoes/ cartilha-censo-2010-pessoas-com-deficienciareduzido.pdf

Lattal, K. (2004). Ciência, Tecnologia e Análise do Comportamento. In J. E. Abreu-Rodrigues \& M. R Ribeiro (Eds.), Análise do comportamento: Pesquisa, teoria e Aplicação. Brasília, DF: Artmed.

Law No. 8.213. (1991). Dispõe sobre os Planos de Benefícios da Previdência Social e dá outras providências. Retrieved from http://www.planalto.gov.br/ccivil_03/leis/18213cons.htm

Pereira-Silva, N. L., \& Furtado, A. V. (2014). Inclusão no trabalho: A vivência de pessoas com deficiência intelectual. Interação em Psicologia, 16(1), 95-100. doi: http://dx.doi.org/10.5380/ psi.v16i1.23012 
Toldrá, R. C., De Marque, C. B., \& Brunello, M. I. B. (2010). Desafios para a inclusão no mercado de trabalho de pessoas com deficiência intelectual: Experiências em construção. Revista de Terapia Ocupacional da Universidade de São Paulo, 21(2), 158-165. doi: http://dx.doi.org/10.11606/ issn.2238-6149.v21i2p158-165

Veltrone, A. A., \& Almeida, M. A. (2010). Perfil da pessoa com deficiência no mercado de trabalho na cidade de São Carlos-SP. Revista Educação Especial (Santa Maria), 23(36), 73-90. doi: $10.5902 / 1984686 \mathrm{X}$

Received: 21/10/2016

$1^{\text {st }}$ revision: $16 / 05 / 2017$

Accepted: 17/05/2017 distribution, and reproduction in any medium, provided you give appropriate credit to the original author(s) and the source, provide a link to the Creative Commons license, and indicate if changes were made. 